\title{
Inhibition of Barnacle Settlement by Ekofisk Crude Oil
}

\author{
Walter G. Nelson* \\ Institute of Marine Biology, University of Bergen, N-5065 Blomsterdalen, Norway
}

\begin{abstract}
Inhibition of settlement of the larvae of the barnacle Balanus balanoides was observed to result from experimental applications of weathered Ekofisk crude oil to bare rock surfaces in the intertidal zone of a Norwegian fjord. The degree of inhibition appeared to be related to the oil concentration applied. B. balanoides settlement on heavily oiled surfaces was initially less than $1 \%$ of that on unoiled squares; squares initially receiving $1 / 3$ this amount of oil showed only a $50 \%$ reduction in barnacle settlement.
\end{abstract}

\section{INTRODUCTION}

Steady expansion of oil exploration and oil production activities into northern latitudes has resulted in increasing attention to the ecological impact of oil spills and the recovery of oil-fouled northern marine ecosystems (Vandermeulen, 1978; Kineman et al., 1980). Following an oil spill, a key factor in the recovery of oil-fouled rocky intertidal communities in northern latitudes will be larval settlement by the intertidal invertebrate species composing such communities. In one of the few published field experiments with oil in rocky intertidal systems, Crapp (1971) has shown some indication that spatfall of the barnacle Balanus balanoides may be decreased by oil dispersant runoff, but is largely unaffected by crude oil alone. This paper presents data showing that the presence of crude oil can prevent, almost totally, the once-yearly settlement of the larvae of $B$. balanoides.

\section{MATERIALS AND METHODS}

Larval recolonization experiments were carried out in the rocky intertidal zone of a moderately exposed location near the Institute of Marine Biology of the University of Bergen, Bergen, Norway, Fifteen patches, each $0.01 \mathrm{~m}^{2}$ in area, were scraped to bare rock. Five of the squares served as unoiled controls, 5 were oiled by

\footnotetext{
- Present address: US Environmental Protection Agency, Marine Science Center, Newport, Oregon 97365, USA
}

spraying with $20 \mathrm{ml}$ of Ekofisk crude oil per square (a concentration equal to $2 \mathrm{l} \mathrm{m}^{-2}$ ), and 5 were oiled on 3 consecutive days with $6.6 \mathrm{ml}$ Ekofisk crude oil per square. A second experiment started with two intact squares, each $0.04 \mathrm{~m}^{2}$ in area. One of these was sprayed with $80 \mathrm{ml}$ Ekofisk crude $\left(2 \mathrm{l} \mathrm{m}^{-2}\right)$, then both the oiled and the remaining unoiled square were scraped to bare rock after $1 \mathrm{~h}$. The oil used in both experiments was weathered before use; it was subjected to mechanical mixing with seawater for $3 \mathrm{~d}$, allowed to separate, and recovered through a separatory funnel. Larval settlement was monitored photographically. Counts were obtained of Balanus balanoides settling in 3 randomly located $9 \mathrm{~cm}^{2}$ quadrats per settlement square in the first experiment, and in 12 such quadrats per settlement square in the second experiment. Results were compared using oneway analysis of variance.

\section{RESULTS}

Significant differences in Balanus balanoides settlement were clearly seen after $24 \mathrm{~h}$ (Fig. 1), and these differences persisted through the period of larval settlement. B. balanoides settlement on the heavily oiled squares initially was less than $1 \%$ of that on unoiled squares, whereas squares initially receiving one-third this amount of oil showed only a $50 \%$ reduction in barnacle settlement. After $3 \mathrm{~d}$, the total amount of oil applied to both sets of oiled squares was the same, yet the squares that had received multiple moderate doses 


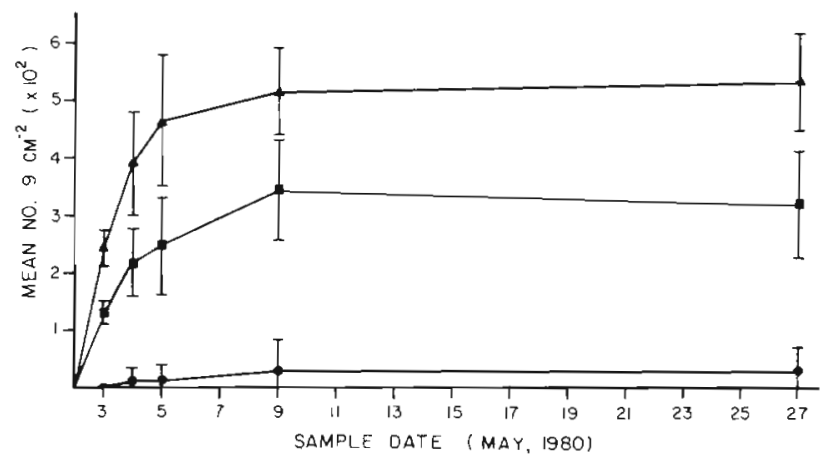

Fig. 1. Balanus balanoides. Mean density ( \pm 1 standard deviation) of larvae settling on bare rock surfaces. $\Delta=$ control (no oil); $=$ oiled on each of 3 consecutive days with $6.3 \mathrm{ml}$ day $^{-1}$ square $^{-1} ;=$ oiled once with $20 \mathrm{ml}$ square $^{-1}$. All differences between treatments on any sample date are significantly different $(p \ll 0.001)$

of oil showed $250 \%$ greater settlement of barnacles than those squares receiving a single heavy dose. Table 1 indicates that even when oil was applied to the extant community and these animals were removed, sufficient oil remained to significantly inhibit $B$. balanoides settlement (number settling per $9 \mathrm{~cm}^{2}$ : unoiled, $184.8 \pm 31$; oiled, $111.6 \pm 34.2$ ). The degree of reduction in this instance resembled that of the multiple oiling treatment in the first experiment. Both experiments suggest that inhibition of barnacle settlement by crude oil may be directly concentration-dependent.

Table 1. Balanus balanoides. Analysis of variance comparing density of settling larvae on oiled and unoiled squares, scraped to bare rock after oiling

\begin{tabular}{|lrrrrr|}
\hline $\begin{array}{l}\text { Source of } \\
\text { variation }\end{array}$ & df & $\begin{array}{r}\text { Sum of } \\
\text { squares }\end{array}$ & $\begin{array}{c}\text { Mean } \\
\text { square }\end{array}$ & $\begin{array}{c}F \\
\text { value }\end{array}$ & $F_{0.05}$ \\
\hline Treatments & 1 & 32,120 & $32,120.2$ & 30.0 & 4.3 \\
Quadrats & 22 & 23,523 & $1,069.2$ & & \\
Total & 23 & 55,643 & & & \\
\hline
\end{tabular}

\section{DISCUSSION}

The results of these experiments relate to the potential impact of oil spills on rocky intertidal communities in northern latitudes. Balanus balanoides is a primary component of upper intertidal communities on the Norwegian coast (Brattegard, 1966) and in many other northern areas (e.g. Lewis, 1964). B. balanoides reproduces only once annually (Nilsson-Cantell, 1978), mass occurrence of cyprid larvae being noted for only 1-2 weeks (Blom and Nyholm, 1961). The majority of settlement may take place over a period of $5 \mathrm{~d}$ (Blom and Nyholm, 1961). As shown by the present experi- ments, an oil spill during this critical period resulting in concentrations reaching the shore of approximately $21 \mathrm{~m}^{-2}$ (e.g. roughly equivalent to the Dounreay oil spill; Bowman, 1978) could result in an almost total lack of settlement by barnacles in the intertidal zone for that year in the affected area. Such a potentially major effect on larval settlement is in sharp contrast to results of work in progress indicating that similar concentrations of Ekofisk crude oil have little or no effect on survival of adult $B$, balanoides under field conditions. Myers et al. (1980) have recently observed mortality of juvenile $B$. balanoides due to spilled Saudi Arabian crude oil, although they observed similar settlement at oiled and unoiled sites. Whether this apparent lack of inhibition of settlement was due to the difference in oil type or to an insufficient concentration on the shore remains an open question.

Total or partial reduction in Balanus balanoides settlement and recruitment might result in significant shifts in the species composition of the community. Indications are that the effects of crude oil on recruitment of rocky intertidal invertebrate species persist for relatively short periods (Crapp, 1971; Straughan, 1971; Chan, 1975; Nelson, unpubl.). The possibility therefore exists that other species reproducing later, and usually being prevented from recruiting by the presence of barnacles, might be more successful during settlement and recruitment. In the intertidal community studied, settlement of several other important species (Mytilus edulis and fucoid algae) on barnacles also appeared to be much greater than on bare rock ( $K$. Erstad, IMB, Bergen, pers. comm.). As a result, a failure of barnacle settlement could lead to major modifications of community composition by either pathway, and these changes could persist. Changes in rocky intertidal community structure generated by oil-related perturbations have been shown to persist for as long as $10 \mathrm{y}$ (Southward and Southward, 1978) in England. In colder waters, with shorter seasons of growth and reproduction, conceivably they might persist even longer.

The critical nature of the timing and concentration of oil necessary to produce significant inhibition of larval settlement by Balanus balanoides is probably why such inhibition has not been previously reported. It is clear that further controlled field experiments are necessary to identify other potentially important but non-obvious consequences of oil pollution in marine ecosystems.

Acknowledgements. Ekofisk crude oil was kindly supplied by the Monstad refinery of Rafinor A/S through the agency of $\mathrm{T}$. Bakke of the Havforsknings Institutt. The work was supported by the Norges Teknisk-Naturvitenskapelige Forskninsrâd Fellowship, by the Institute of Marine Biology of the University of Bergen, and by Forskningsprogram om Havforurensniger Project 202 


\section{LITERATURE CITED}

Blom, S.-E., Nyholm, K.-K. (1961). Settling times of Balanus balanoides (L), Balanus crenatus Brug. and Balanus improvisus Darwin on the West Coast of Sweden. Zool. Bidr Upps. 33: 149-155

Bowman, R. S. (1978). Dounreay oil spill: Major implications of a minor incident. Mar. Poll. Bull. 9: 269-273

Brattegard, T (1966). The natural history of the Hardangerfjord. 7 Horizontal distribution of the fauna on rock shores. Sarsia 22: 1-54

Chan, G. L. (1975). A study of the effects of the San Francisco oil spill on marine life. Part II: Recruitment. In: Proceedings of the conference on prevention and control of oil spills, 1975. American Petrolum Institute, Washington, pp. $457-461$

Crapp, G. B. (1971). Field experiments with oil and emulsifiers. In: Cowell, E. B. (ed.). The ecological effects of oil pollution on littoral communities. Institute of Petroleum, London, pp. 114-128

Kineman, J. J., Elmgren, R., Hansson, S. (1980). The Tsesis oil spill, US Department of Commerce, NOAA, Boulder
Lewis, J. R. (1964). The ecology of rocky shores, English Universities Press, London

Myers, A. A., Southgate, T., Cross, T F. (1980). Distinguishing the effects of oil pollution from natural cyclical phenomena on the biota of Bantry Bay, Ireland. Mar. Poll. Bull. 11: 204-207

Nilsson-Cantell, C.-A. (1978). Cirripedia, Thoracica and Acrothoracica, Universitetsforlaget, Oslo

Southward, A. J., Southward, E. C. (1978). Recolonization of rocky shores in Cornwall after use of toxic dispersants to clean up the Torrey Canyon spill. J. Fish Res. Bd Can. 35: $682-706$

Straughan, D. (1971). Breeding and larval settlement of certain intertidal invertebrates in the Santa Barbara Channel following pollution by oil. In: Straughan, D. (ed.) Biological and oceanographical survey of the Santa Barbara Channel oil spill 1969-1970. Allan Hancock Foundation, Los Angeles, pp. 223-244

Vandermeulen, J. H. (1978). Introduction to the symposium on recovery potential of oiled marine northern environments. J. Fish. Res. Bd Can. 35: 505-508 